\title{
Controversies in the Description of Congenitally Malformed Hearts
}


This page is intentionally left blank 


\section{Controversies in the}

\section{Description of Congenitally Malformed Hearts}

\section{R. H. Anderson}

Imperial College School of Medicine

\section{A. E. Becker}

Academic Medical Centre, University of Amsterdam 
Published by

Imperial College Press

516 Sherfield Building

Imperial College

London SW7 2AZ

\title{
Distributed by
}

World Scientific Publishing Co. Pte. Ltd.

P O Box 128, Farrer Road, Singapore 912805

USA office: Suite 1B, 1060 Main Street, River Edge, NJ 07661

UK office: 57 Shelton Street, Covent Garden, London WC2H 9HE

\author{
British Library Cataloguing-in-Publication Data \\ A catalogue record for this book is available from the British Library.
}

\section{CONTROVERSIES IN THE DESCRIPTION OF CONGENITALLY MALFORMED HEARTS}

Copyright $\odot 1997$ by Imperial College Press

All rights reserved. This book, or parts thereof, may not be reproduced in any form or by any means, electronic or mechanical, including photocopying, recording or any information storage and retrieval system now known or to be invented, without written permission from the Publisher.

For photocopying of material in this volume, please pay a copying fee through the Copyright Clearance Center, Inc., 222 Rosewood Drive, Danvers, MA 01923, USA. In this case permission to photocopy is not required from the publisher.

ISBN 1-86094-067-6

Printed in Singapore. 


\section{Foreword}

The morphologic examination of congenitally malformed hearts has moved a long way. Initially, the anomalous organs were described very much as what they were - pathological curiosities. Indeed, in early times the birth of an infant with a congenital malformation was considered an illomen. With increasing experience, physicians began to collect and categorize the cases. An excellent example of the art of description was provided by Peacock, working in London in the middle of the nineteenth century. Von Rokitansky, practising in Vienna about twenty years later, demonstrated the potential value of cardiac anomalies as a proving ground for theories of embryogenesis. It was Fallot, however, working all his life in Marseilles, who showed the value of clinico-pathological correlation, clarifying the cause of "la maladie bleue". Other giants then left their footprints during the first half of the twentieth century, notably Maud Abbott working in Montreal, Canada. This marked the shift of innovative morphologic thinking to the America's and, during the 1960's and early 1970's, two morphologists developed, in parallel, the segmental approach to diagnosis of congenital heart malformations. They were Richard van Praagh, working in sequence in Toronto, Rochester (Minnesota), and Boston, and Maria Victoria de la Cruz from Mexico City. Along with other notable pathologists, particularly Jesse Edwards and Maurice Lev, these investigators laid the foundations of our present-day understanding of congenital cardiac anomalies. But, despite the considerable steps made, controversies remain, particularly with respect to the best, and the most accurate, way to describe and categorize some of the more complex malformations. We have been involved in many of these controversies.

It is these persisting differences which will provide the focus for this book, and the videodemonstrations it accompanies. Richard Van Praagh once commented that the wine of understanding may, on occasion, need to be poured into new bottles, but the old bottles should not be smashed. We agree totally with this philosophy. Another saying is that good wine needs no bush. So it is with cardiac anatomy, which is immediately apparent to all who seek to observe it. It is the interpretations of the observed anatomy which vary. In this book, and the accompanying videotapes, therefore, we have attempted to demonstrate the good wine, needing no bush. We then discuss the old, and the new, bottles in which it has matured. Obviously, we have, and recognize, our biases. Notwithstanding this, we have tried to present the controversies, as best we can, in balanced fashion. 
As with so many of our works, the current project would not have been completed without the support of our clinical colleagues, and those with whom we have collaborated with in the past. With this particular undertaking, we owe a particular debt to Siew Yen Ho, Christine Anderson, and Karen McCarthy, who worked over and above the call of duty to produce the manuscript and illustrations. The videotapes could not have been completed without the tireless help and support of Jeremy Weaver and Andrew Williamson. Finally, it is a pleasure to acknowledge our indebtedness to Nancy Vaughan, of Imperial College Press, who is everything an Editor should be. 


\section{Contents}

Foreword $v$

$\begin{array}{lll}\text { Chapter } 1 & \text { Introduction } & 1\end{array}$

$\begin{array}{lll}\text { Chapter } 2 & \text { Atrioventricular Septal Defects } & 18\end{array}$

$\begin{array}{lll}\text { Chapter } 3 & \text { Hearts with Isomeric Atrial Appendages } & 67\end{array}$

Chapter 4 Tetralogy of Fallot and Double Outlet Right Ventricle 113

Chapter 5 Hearts with Univentricular Atrioventricular Connection 149

$\begin{array}{ll}\text { Index } & 195\end{array}$ 